\title{
The role of Chromium III in the organism and its possible use in diabetes and obesity treatment
}

\author{
Sławomir Lewicki' ${ }^{1}$ Robert Zdanowski', Małgorzata Krzyżowska', Aneta Lewicka², \\ Bogdan Dębski ${ }^{3}$, Marcin Niemcewicz ${ }^{4}$, Mariusz Goniewicz ${ }^{5}$ \\ ${ }^{1}$ Department of Regenerative Medicine, Military Institute of Hygiene and Epidemiology, Warsaw, Poland \\ ${ }^{2}$ Department of Hygiene and Physiology, Military Institute of Hygiene and Epidemiology, Warsaw, Poland \\ ${ }^{3}$ Division of Biochemistry, Department of Physiological Sciences, Faculty of Veterinary Medicine, University of Life Sciences \\ (SGGW), Warsaw, Poland \\ ${ }^{4}$ Biological Threats Identification and Countermeasure Centre of the Military Institute of Hygiene and Epidemiology, Puławy, \\ Poland \\ ${ }^{5}$ Emergency Medicine Unit, Medical University, Lublin, Poland \\ Lewicki S, Zdanowski R, Krzyżowska M, Lewicka A, Dębski B, Niemcewicz M, Goniewicz M. The role of Chromium III in the organism and its \\ possible use in diabetes and obesity treatment. Ann Agric Environ Med. 2014; 21(2): 331-335. doi: 10.5604/1232-1966.1108599
}

\section{Abstract}

Introduction. Diabetes and obesity are diseases characterized by their increasing incidence every year. When comparing with healthy subjects, the serum levels of chromium $(\mathrm{Cr})$ are lowered in these two diseases. Several studies conducted in laboratory animals with experimentally- induced diabetes demonstrated that supplementation with chromium ions (III) decreased glucose concentration in the blood, reduced the probability of atherosclerosis and heart attack, lowered the levels of cholesterol and low density lipoprotein (LDL). The Importance of chromium is actually challenged due to lack of clear manifestations of $\mathrm{Cr}$ deficiency in humans and animals.

Objective. The aim of this review was to present current knowledge about $\mathrm{Cr}$ its role in the organism and possible mechanisms of its action also in metabolic disorders such as diabetes or obesity.

State of knowledge. In the last decade, $\mathrm{Cr}$ was established to be rather a beneficial than essential trace element in mammals, and has gained popularity as a nutritional supplement and a component of many multivitamin/mineral formulations, fortified food and energy drinks. Cr supplements are widespread for diabetes and obesity treatment, despite conflicting reports on its efficacy. It was suggested that $\mathrm{Cr}$ shows a beneficial influence upon glucose and lipid disturbances.

Conclusions. The recent clinical trials provided evidence both in favor and against the importance of $\mathrm{Cr}$ in healthy and ill organisms. Unfortunately, also the molecular mechanism by which chromium affects glucose and lipid metabolism is still unclear. Beneficial effects of diet supplementation with different sources of $\mathrm{Cr}^{3+}$ can be potentially explained by rather pharmacological than nutritional effects.

Key words

chromium, diet, diabetes, obesity, sugar/lipids metabolism

\section{INTRODUCTION}

Chromium (Cr) is an ubiquitous metal, occurring in water, soil and biological systems. The three most stable forms of chromium occurring in the environment are: $0,+3$, and +6 valence state; metal and alloys, trivalent chromium, and hexavalent chromium, respectively. Trivalent chromium is considered to be an essential element, both in animal feeding and human nutrition. In late 1950s, Schwarz and Mertz reported that feeding rats with a Torula- yeast-based diet resulted in the development of impaired glucose tolerance, and the authors indentified $\mathrm{Cr}^{3+}$ as an integral part of the protein recognized as glucose tolerance factor (GTF) [1]. The evidence on the essential $\mathrm{Cr}$ role in total parenteral nutrition (TPN) of patients has been presented $[2,3]$. However, a limited number of patients demonstrating a variety of symptoms and their different health status make these observations questionable. In animals, no symptoms of adverse effects of low levels of $\mathrm{Cr}$ in feeds have been observed. Furthermore, reproduction of experiments in rats fed with Torula yeast did not provide evidence that chromium is an essential element

Address for correspondence: Sławomir Lewicki, Department of Regenerative Medicine, Military Institute of Hygiene and Epidemiology, Warsaw, Poland e-mail: lewickis@gmail.com

Received: 16 October 2012; accepted: 06 May 2013
[4]. However, other authors regard chromium (III) as an essential trace element and/or showing beneficial effects in humans [5].

This trace element is involved in the metabolism of carbohydrates, lipids, and proteins mainly by increasing the efficiency of insulin. Chromium deficiency affects the maintenance of normal glucose tolerance and healthy lipid profiles. The suggestion that $\mathrm{Cr}$ intake is generally low has generated interest regarding the supposed beneficial effects of $\mathrm{Cr}$ supplementation on biological function and health of animals and humans. In the USA in 2001, the dietary guidelines for daily chromium uptake was lowered from 50-200 for adults to 35 and $25 \mu \mathrm{g}$ for men and women, respectively (Food and Nutrition Board at the Institute of Medicine).

This review presents current knowledge about chromium, its role in the organism and possible mechanisms of action. The role of $\mathrm{Cr}$ supplementation in metabolic disorders such as diabetes and obesity, as well as in healthy organisms, is discussed.

Absorption, bio-distribution and excretion. Chromium is absorbed together with other metal ions in the gut through the unsaturated passive transport [6]. The efficiency of this process is very low with the average absorption ranging from 
$0.4-2.5 \%$ [7]. The absorption process depends on the $\mathrm{Cr}$ content in the diet and on the chemical form of this element and other food components. Studies conducted in rats showed increased absorption of $\mathrm{Cr}$ used in the form of nicotinate (1.3\%) and picolinate $(1.1 \%)$ in comparison to chromium chloride $(0.9 \%)$ [8]. It was shown that absorption of $\mathrm{Cr}$ in humans in the form of chromium chloride is much lower $(0.1-0.4 \%)$ than of chromium picolinate $(2.8 \%)$ or chromium given as the yeast chromium (5-10\%) [7,9]. Organic sources of $\mathrm{Cr}$ (i.e. picolinate, or propionate-methionine salt) are much better absorbed than inorganic forms (e.g. oxides), and lead to the increase of these compounds concentration in tissues [10]. The highest dose-accumulation correlation of $\mathrm{Cr}$ in the tissues is observed after administration of $\mathrm{Cr}$ nanoparticles $[11,12]$. However, other factors present in the diet show a significant impact on the amounts of $\mathrm{Cr}$ absorbed from the gastrointestinal tract. Starch, simple sugars, ascorbic acid, oxalic acid, nicotinic acid, some amino acids, aspirin increase absorption of this element [13-16], while high concentrations of phosphate, calcium, magnesium, titanium, zinc, vanadium and iron reduce the rate of this process $[13,17]$.

After absorption from the intestine, chromium (III) is released into the bloodstream where it is bound by proteins involved in iron metabolism. In vitro and in vivo studies in rats have shown that about $80 \% \mathrm{Cr}$ in the blood is associated with transferrin [18]. In this complex, $\mathrm{Cr}$ is transported to the cells, and the efficiency of Cr transfer through the cell membrane depends on insulin concentration [19].

Chromium is found in all animal tissues and is present at the concentrations of several to tens of $\mu \mathrm{g} / \mathrm{kg}$, rarely exceeding $100 \mu \mathrm{g} / \mathrm{kg}$ [20]. The highest concentrations are found in the liver, kidneys and spleen, while slightly lower levels are observed in heart, muscle, pancreas, lungs, bones and brain $[21,22]$. It has been shown that certain tissues, such as bones, testis and epididymis, are capable of storing CR in a long-term manner, in comparison to heart, pancreas or brain, where the turnover of chromium ions is relatively short [23].

Supplementation with chromium ions in livestock reveals differences in the accumulation of this element in the tissues. In pigs, feed enrichment with $0.2 \mathrm{mg}$ of $\mathrm{Cr} / \mathrm{kg}$ caused its accumulation in the liver and kidneys, with no clear impact on the concentration in the muscle, while in cattle, no significant changes of Cr levels in the tissues and major organs were observed [24]. Studies in poultry revealed that $\mathrm{Cr}$ administration in various forms (yeast, chromium, picolinate, chromium chloride) cause accumulation of this element in the liver, kidneys and muscles, without significant differences found for the eggs of hens $[25,26]$.

More than $80 \%$ of $\mathrm{Cr}$ is removed from the body in the form of urine, while the remaining part of this element is excreted via faeces and sweat [27]. In humans, consumption of large amounts of sugar, exhaustive physical exercise, pregnancy and lactation leads to increased Cr excretion in the urine [28]. Negative Cr balance was observed in patients suffering from diabetes type 1 [29]; enhanced secretion of this element in the urine was also found in rats after intramuscular injection of insulin [30].

The role of chromium in the body. The first information in the literature suggesting a biological role for chromium appeared in the late 1950s [1], while in 1996, Cr was considered as a trace element necessary for proper functioning of living organisms [31]. Currently, the essential role of $\mathrm{Cr}$ is questioned, mainly due to the lack of clear manifestations of $\mathrm{Cr}$ deficiency in mammals [4, 32]. It has been suggested that $\mathrm{Cr}$ should be classified as a factor nutritionally or pharmacologically beneficial $[33,34]$.

Chromium III is involved in many different processes including sugar and lipids metabolism. In the studies conducted in cattle and rats, diet supplementation with high amounts of $\mathrm{Cr}$ decreased the levels of total cholesterol, LDLcholesterol, triglycerides and non-esterified fatty acids; the increased levels of HDL-cholesterol and the beta-oxidation process were also observed [35-38]. Similar properties of $\mathrm{Cr}$ were noticed in experiments with murine myogenic C2C12 cell lines [39]. Supplementation with chromium ions (III) (above $1 \mathrm{mg} / \mathrm{kg}$ body weight) also caused a dosedependent reduction in serum leptin concentrations in rats. A similar trend was observed in human studies $[35,40]$. It was shown that $\mathrm{Cr}$ supplementation increased the rate of amino acids transport into the cells. In the study by Lindeman et al. in 2007, a trend to decrease serum level of a stress hormone - cortisol, was noticed, however, without a clear correlation between these two factors [41]. Chromium can affect biological effects induced also by other trace elements. The common transport mechanism for chromium and iron makes these metals compete for the binding site of transferrin. In rats treated intraperitoneally with chromium ions, reduction in the bioavailability of iron in the body, with the onset of symptoms characteristic of anaemia, was observed [42]. It was shown that oral administration of $\mathrm{Cr}$ (as chromium nitrate) counteracts the effects of the selenium anti-carcinogenic mechanisms in the growth and latency of murine mammary tumour induced by the MMTV virus [43]. Chromium is engaged in the proper functioning of the immune system [44]. The use of Cr to both in vivo and in vitro studies modified the levels of several cytokines: IL-1, IL-2, IL-6, IFN and TNF- $\alpha[45,46]$. It was suggested that a nutrigenomic study may shed more light on the mechanisms of Cr-gene interaction, and provide a better understanding of the chromium mode of action [47].

Possible mechanism of action. Despite numerous studies, there is no clear explanation how chromium ions influence carbohydrate and lipid metabolism. There are several theories which explain chromium impact on the glucose metabolism. Among these, the most widely accepted hypothesis is the involvement of an oligopeptide, named chromodulin (LMWCr, a low-molecular weight chromium-binding substance) $[48,49]$. LMWCr is a small peptide with a mass of about 1,500 kDa, built only of amino acids: 2 glycine, 2 cysteine, 4 glutamic acid and 2 molecules of aspartic acid [50]. It has an ability to bind four chromium atoms, and only in this form it shows its full biological activity [51]. Vincent et al. (1999) explained the mechanisms of chromium ions uptake and insulin receptor kinase activation by chromodulin [52]. According to the proposed mechanism, LMWCr is present in the cytoplasm and nucleus of the cells sensitive to insulin in an inactive form called 'apochromodulin'. Upon insulin binding, the transferrin receptor is activated, which further leads to internalization of transferrin-chromium complex into the cell. Internalization of this complex causes activation of the ATP-dependent proton pump, decrease of $\mathrm{pH}$, release of $\mathrm{Cr}$ from transferrin and its binding by chromodulin. After binding of four chromium atoms, a chromodulin molecule is converted into a biologically-active 'holochromodulin' which 
binds to the insulin receptor beta subunit, previously activated by the hormone, resulting in activation of receptor tyrosine kinase and insulin signal amplification. As a result, activation of the intracellular insulin signal transduction system leads to the co-localization of GLUT4 protein (glucose transporter protein 4) to the cell membrane. GLUT4 is the principal glucose transporter mediating glucose transport through the cell membrane [53]. However, the exact structure of LMWCr remains unknown. New information concerning the sequence of this oligopeptide and $\mathrm{Cr}$ binding properties has been recently provided by Chen et al, 2011 [54]. However, the experiments with $\mathrm{Cr}$ supplementation can be also interpreted as a result of non-specific binding of $\mathrm{Cr}$ to the amino acid sequences. These types of proteins were found in rat liver (9 proteins with a molecular weight from $4-97 \mathrm{kDa}$ ) and bovine liver $(15.6 \mathrm{kDa})[18,55]$. Furthermore, chromodulin activity stimulating the insulin receptor tyrosine kinase is unspecific. It was observed that activation of tyrosine kinase by insulin may be also caused by other metal ions, such as zinc, manganese, cadmium and certain xenobiotics, e.g. metformin and pioglitazone [56].

Another theory about the role of Cr in glucose metabolism indicates for a direct insulin receptor activation by chromium ions. Balamurugan et al. [57] showed that high levels of chromium caused induction of ROS synthesis in lymphocytes. A similar effect for the myogenic $\mathrm{C} 2 \mathrm{C} 12$ cell line was observed. Chromium increased ROS synthesis (about $400 \%$ of initial ROS concentration) after 1 min. of administration, then cyclic decreases and increases were observed with a similar effect to insulin administration. This effect was due to the changes in the membrane phosphatases activity. The authors suggest that ROS are essential and necessary for the optimal metabolic effect of chromium ions.

One of the new concepts of $\mathrm{Cr}$ action was proposed by Pattar, et al [58] who formulated a hypothesis that chromium ions affect the membrane fluidity and thereby regulate the uptake of glucose by the cells. This effect was associated with the reduced cholesterol content in the cell membrane, which is considered a factor lowering glucose transport controlled by the insulin receptor. In addition, these authors showed no effect of chromium ions on the phosphorylation of the insulin signal transduction proteins: IR-beta, IRS, PI 3-K and Akt-1. Results a study Raja et al. showed the ability of $\mathrm{Cr}$ to interact and modify the structure of lipid bilayers [59].

It is also possible that the mode of action of $\mathrm{Cr}$ depends on activation of the estrogen receptor. It is assumed that estrogen may act through two signaling pathways: insulin receptordependent (IR) and the receptor for insulin-like growth factor (IGF-1) -dependent [60]. It has been shown that $\mathrm{Cr}$ is a metal possessing estrogenic properties and it can stimulate transcription of genes in cells containing estrogen receptor $[61,62]$. Molecular mechanism of estrogen influence on insulin-stimulated processes is not fully recognized. It can be divided into two parts: a fast signal (related with membrane estrogen receptors activation) and a slow signal (related with nucleus estrogen receptors activation). Some new evidence on the chromium estrogenic properties is provide in the doctoral dissertation by Lewicki [63]. The microarray profiles of $\mathrm{Cr}$ and estrogen treated $\mathrm{C} 2 \mathrm{C} 12$ cells (mouse myocytes) were almost similar. It was observed that out of 24 genes, the expression of which was altered by supplementation with chromium ions $\mathrm{Cr}^{3+} 10 \mathrm{ug} / \mathrm{L}, 19$ genes were common with those that were estradiol-induced (10 nM).
Chromium in diabetes and obesity. Diabetes and obesity are diseases of the most serious public health concern. It is estimated that each year the number of new patients with diabetes increases by millions of people $(700,000$ in the USA, 110,000,000 in Asia), while obesity is a problem for more than $15 \%$ of Europeans and $20 \%$ of North Americans [64-66]. Treatment of the symptoms and complications of diabetes worldwide consume huge funds; only in USA, billions of dollars are allocated yearly for this purpose [67]. In both cases, serum levels of $\mathrm{Cr}$ are lower, compared with healthy individuals $[68,69]$. Since chromium (III) modulates insulin action and glucose homeostasis, diabetes and obesity are logical candidates for $\mathrm{Cr}$ replacement therapy. Positive outcomes of $\mathrm{Cr}$ supplementation included reduction in the used hypoglycaemic medication and decrease in glucose concentration, cholesterol and triglyceride in the blood. However, the results of different studies are often contradictory.

Several studies conducted in laboratory animals with experimentally-induced diabetes, demonstrated that supplementation with chromium ions (III) decreased glucose concentration in the blood, reduced the probability of atherosclerosis and heart attack, as well as lowered cholesterol and low density lipoprotein - LDL $[70,71,72]$. It has been suggested $[73,74,75]$ that $\mathrm{Cr}$ concentration increases phosphorylation of enzymes associated with the postreceptor insulin signaling: IR, IRS1, GDP and PKC $\zeta$ (p-IRTyr, p-IRS1Tyr, p-PKBSer, p-PKCלThr). Animals consuming a chromium-enriched diet were tested for tolerance to oral administration of glucose (OGT), and showed a faster metabolism of glucose, compared to those which were treated with a low $\mathrm{Cr}$ diet. In human with diabetes 2, Cr supplementation can improve glucose metabolism and insulin action [76, 77, 78]. A similar effect was shown in patients with severe insulin resistance, who were given i.v. infusion of chromium (III) $[79,80]$. Based on the own study results, Jain et al. (2012) [81] concluded that Cr supplementation has a potential as an adjunct therapy for patients suffering from type 2 diabetes. Interestingly, Cefalu et al. [82] observed that a consistent effect of $\mathrm{Cr}$ action in subjects with type 2 diabetes may be related with their genetic phenotype.

There are also several publications describing a positive role of $\mathrm{Cr}$ in the reduction of lipids content and body mass in obese humans and animals [70, 83, 84]. However, other studies showed lack of $\mathrm{Cr}$ protective function in metabolic syndrome observed for obese but non-diabetic adults [85].

Unfortunately, there are only a few studies concerning the effect of $\mathrm{Cr}$ supplementation on the metabolism of carbohydrates and lipids levels in healthy individuals. These studies are mostly a guesswork. A systematic review of randomized controlled trials evaluating $\mathrm{Cr}$ supplementation showed lack of beneficial effects in healthy individuals $[86,87]$. In studies with a controlled energy intake, no decrease in body weight in $\mathrm{Cr}$ supplemented ( $200 \mu \mathrm{g} \mathrm{Cr} / \mathrm{d})$ subjects was observed $[88,89]$. Despite the high popularity of Cr supplementation, it seems that it is not effective in producing a sustained weight loss. However, it was shown for overweight or obese patients that a long-term use of vitamins B6 and B12 and Cr were significantly associated with a lower weight gain [90].

In non-obese, non-diabetic subjects, $\mathrm{Cr}$ therapy was shown not only to have no effect on the insulin sensitivity improvement, but it paradoxically declined its sensitivity [91]. 


\section{CONCLUSIONS}

Many report have shown that chromium III ions have beneficial properties for the organism with disturbances of glucose or lipids metabolism. However, data from the experiments conducted in healthy individuals quite often explicitly show lack of any favourable impact of chromium on sugar/lipids metabolism. This in turn leads to the hypothesis that chromium ions supplementations have been beneficial only in 'disordered organisms'. For the other roles of chromium in the body, we should use this supplement in a reasonable manner, being aware of its possible side-effects.

\section{REFERENCES}

1. Schwarz K, Mertz W. Chromium (III) and the glucose tolerance factor. Arch Biochem Biophys. 1959; 85: 292-295.

2. Jeejeebhoy KN, Chu RC, Marliss EB, Greenberg GR, Bruce-Robertson A. Chromium deficiency, glucose intolerance, and neuropathy reversed by chromium supplementation in a patient receiving long-term total parenteral nutrition. Am J Clin Nutr. 1977; 30(4): 531-538.

3. Freund H, Atamian S, Fischer JE. Chromium deficiency during total parenteral nutrition. JAMA 1979; 241(5): 496-498.

4. Di Bona KR, Love S, Rhodes NR, McAdory D, Sinha SH, Kern N, et al. Chromium is not an essential element for mammals: effects of a "lowchromium" diet. J Biol Inorg Chem. 2011; 16(3): 381-390.

5. Weksler-Zangen S, Mizrahi T, Raz I, Mirsky N. Glucose tolerance factor extracted from yeast: oral insulin-mimetic and insulin-potentiating agent: in vivo and in vitro studies. Br J Nutr. 2012; 108(5): 875-882.

6. Dowling HJ, Offenbacher EG, Pi-Sunyer FX. Absorption of inorganic trivalent chromium from the vascular perfused rat small intestine. J Nutr. 1989; 119(8): 1138-1145.

7. EC (European Commission). Opinion of the Scientific Committee on Food on the Tolerable Upper Intake Level of Trivalent Chromium (expressed in 4 April 2003) http://ec.europa.eu/food/fs/sc/scf/out197_ en.pdf (access: 2010.04.29).

8. Anderson RA, Bryden NA, Polansky MM, Gautschi K. Dietary chromium effects on tissue chromium concentrations and and chromium absorption in rats. J Trace Elem Exp Med. 1996; 9(1): 11-25.

9. Mertz W, Cornatzer WE, editors. Newer Trace Elements in Nutrition. New York, Marcel Dekker, 1971.

10. Ohh SJ, Lee JY. Dietary chromium-methionine chelate supplementation and animal performance. Asian-Aust. J Anim Sci.2005; 18(6): 898-907.

11. Wang MQ, He YD, Lindemann, MD, Jiang, ZG. Efficacy of Cr (III) supplementation on growth, carcass composition, blood metabolites, and endocrine parameters in finishing pigs. Asian-Aust. J Anim Sci. 2009; 22(10): 1414-1419.

12. Zha LY, Xu ZR, Wang MQ, Gu LY. Effects of chromium nanoparticle dosage on growth, body composition, serum hormones and tissue chromium in Sprague-Dawley rats. J Zhejiang Univ Sci B. 2007; 8(5): 323-330.

13. Chen NS, Tsai A, Dyer IA. Effect of chelating agents on chromium absorption in rats. J Nutr. 1973; 103(8): 1182-1186.

14. Davis ML, Seaborn CD, Stoecker BJ. Effects of over-the-counter drugs on ${ }^{51} \mathrm{Chromium}$ retention and urinary excretion in rats. Nutr Res. 1995; 15(2): 201-210.

15. Offenbacher EG. Promotion of chromium absorption by ascorbic acid. Trace Elem. Elect. 1994; 11, 178-181.

16. Samanta S, Haldar S, Ghosh TK. Production and carcase traits in broiler chickens given diets supplemented with inorganic trivalent chromium and an organic acid blend. Br Poultry Sci 2008; 49(2): 155-163.

17. Hill CH. Mineral interrelationships. In: Prasad AS, Oberleas D (eds.). Trace Elements in Human Health and Disease. New York, Academic Press, 1976.p.281-300.

18. Feng W, Li B, Liu J, Chai Z, Zhang P, Gao Y, et al. Study of chromiumcontaining proteins in subcellular fractions of rat liver by enriched stable isotopic tracer technique and gel filtration chromatography. Anal Bioanal Chem. 2003; 375(3): 363-368.

19. Clodfelder BJ, Vincent JB. The time-dependent transport of chromium in adult rats from the bloodstream to the urine. J Biol Inorg Chem. 2005; 10(4): 383-393.

20. National Research Council (US). Mineral Tolerance of Animals: Second Revised Edition. Washington, National Academies Press, 2005.

21. Feng WY, Ding WJ, Qian QF, Chai ZF. Study on the metabolism of physiological amounts of $\mathrm{Cr}$ (III) intragastrical administration in normal rats using activable enriched stable isotope Cr-50 compound as a tracer. J Radioanal Nucl Chem. 1988; 237(1-2): 15-19.

22. Feng W. The transport of chromium (III) in the body: Implications for function. In: Vincent JB, editor. The nutritional biochemistry of chromium (III). Amsterdam, Elsevier, 2007.p.121-137.

23. Borel JS, Anderson RA. Chromium. In: Frieden E (eds.). Biochemistry of the Essential Ultratrace Elements. New York, Plenum press, 1984. p.175-199.

24. Spears JW, Lloyd KE, Tiffany ME, Socha MT. Effect of supplemental chromium on tissue chromium concentrations in cattle. J Anim Sci. 2004; 82(1): 43

25. Debski B, Gralak M, Bertrandt J, Kłos A. Wpływ karmienia z dodatkiem drożdży wzbogaconych chromem na stężenie cholesterolu, chromu, cynku i miedzi żółtkach jaj kurzych. Żywienie Człowieka i Metabolizm 2001; 28: 889-897 (in Polish).

26. Uyanik F, Eren M, Güçlü BK, Sahin N. Effects of dietary chromium supplementation on performance, carcass traits, serum metabolites, and tissue chromium levels of Japanese quails. Biol Trace Elem Res. 2005; 103(2): 187-197.

27. Ducros V. Chromium metabolism, a literature review. Biol Trace Elem Res. 1992; 32: 65-77.

28. Anderson RA, Bryden NA, Polansky MM, Richards MP. Chromium supplementation of turkeys: effects on tissue chromium. J Agric Food Chem. 1989; 37(1): 131-134.

29. Karagun BS, Temiz F, Ozer G, Yuksel B, Topaloglu AK, Mungan NO, et al. Chromium levels in healthy and newly diagnosed type 1 diabetic children. Pediatr Int. 2012; 54(6): 780-785.

30. Clodfelder BJ, Emamaullee J, Hepburn DD, Chakov NE, Nettles HS, Vincent JB. The trail of chromium(III) in vivo from the blood to the urine: the roles of transferrin and chromodulin. J Biol Inorg Chem. 2001; 6(5-6): 608-617.

31. WHO (World Health Organization) Trace elements in human nutrition and health. Geneva. 1996

32. European Food Safety Authority (EFSA). Safety and efficacy of chromium methionine (Availa $\mathrm{Cr}$ ) as feed additive for all species. EFSA J. 2009; 1043: 1-69.

33. Nielsen FH. Summary: The clinical and nutritional importance of chromium - Still debated after 50 years of research. In: Vincent JB, editor. The nutritional biochemistry of chromium (III). Amsterdam, Elsevier, 1995. p.265-276.

34. European Food Safety Authority (EFSA). Scientific Opinion on the safety of trivalent chromium as a nutrient added for nutritional purposes to foodstuffs for particular nutritional uses and foods intended for the general population (including food supplements). EFSA J 2010; 8(12): 1882.

35. Bennett R, Adams B, French A, Neggers Y, Vincent JB. High-dose chromium(III) supplementation has no effects on body mass and composition while altering plasma hormone and triglycerides concentrations. Biol Trace Elem Res. 2006; 113(1): 53-66.

36. Bunting LD, Tarifa TA, Crochet BT, Fernandez JM, Depew CL, Lovejoy JC. Effects of dietary inclusion of chromium propionate and calcium propionate on glucose disposal and gastrointestinal development in dairy calves. J Dairy Sci. 2000; 83(11): 2491-2498.

37. Lai MH, Chen YY, Cheng HH. Chromium yeast supplementation improves fasting plasma glucose and LDL-cholesterol in streptozotocininduced diabetic rats. Int J Vitam Nutr Res. 2006; 76(6): 391-397.

38. McNamara JP, Valdez F. Adipose tissue metabolism and production responses to calcium propionate and chromium propionate. J Dairy Sci. 2005; 88(7): 2498-2507.

39. Lewicki S, Rattman D, Kuryl T, Snochowski M, Debski B. The effect of chromium (III) on fatty acid metabolism and insulin path related gene expression in mouse myocytes cell line C2C12. Żywność Nauka Technologia Jakość 2009; 16(4): 183-194.

40. Inanc N, Uyanik F, Sahin H, Yaman H, Erdem O. Effects of chromium supplementation on body composition, leptin, ghrelin levels and selected biochemical parameters in obese women Trace Elem Electrolytes 2006; 23(2): 128-133.

41. Lindemann MD. Use of chromium as an animal feed supplement. In: Vincent JB (eds.). The nutritional biochemistry of chromium(III) Amsterdam, Elsevier, 2007. p.85-118.

42. Ani M, Moshtaghie AA. The effect of chromium on parameters related to iron metabolism. Biol Trace Elem Res. 1992; 32: 57-64.

43. Schrauzer GN. Interactive effects of selenium and chromium on mammary tumor development and growth in MMTV-infected female mice and their relevance to human cancer. Biol Trace Elem Res. 2006; 109(3): 281-292.

44. Terpiłowska S, Siwicki AK. The role of selected microelements: selenium, zinc, chromium and iron in immune system. Cent Eur J Immunol. 2011; 36(4): 303-307. 
45. Terpiłowska S, Siwicki, AK. The influence of chromium and iron on interleukin-1 alpha and interleukin- 6 concentration in vitro and in vivo. Cent Eur J Immunol. 2011; 37(2): 106-109.

46. Burton JL, Nonnecke BJ, Dubeski PL, Elsasser TH, Mallard BA. Effects of supplemental chromium on production of cytokines by mitogenstimulated bovine peripheral blood mononuclear cells. J Dairy Sci. 1996; 79(12): 2237-2246

47. Lau FC, Bagchi M, Sen CK, Bagchi D. Nutrigenomic basis of beneficial effects of chromium(III) on obesity and diabetes. Mol Cell Biochem. 2008; 317(1-2): 1-10.

48. Yamamoto A, Wada O, Ono T. Distribution and chromium-binding capacity of a low-molecular-weight, chromium-binding substance in mice. J Inorg Biochem. 1984; 22(2): 91-102.

49. Wada O, Wu GY, Yamamoto A, Manabe S, Ono T Purification and chromium-excretory function of low-molecular-weight, chromiumbinding substances from dog liver. Environ Res. 1983; 32(1): 228-239.

50. Davis CM, Vincent JB. Isolation and characterization of a biologically active chromium oligopeptide from bovine liver. Arch Biochem Biophys. 1997; 339(2): 335-343.

51. Yamamoto A, Wada O, Manabe S. Evidence that chromium is an essential factor for biological activity of low-molecular-weight chromium-binding substance. Biochem Biophys Res Commun. 1989; 163(1): 189-193.

52. Vincent JB. Mechanisms of chromium action: low-molecular-weight chromium-binding substance. J Am Coll Nutr. 1999; 18(1): 6-12.

53. Chen G, Liu P, Pattar GR, Tackett L, Bhonagiri P, Strawbridge AB, et. al. Chromium activates glucose transporter 4 trafficking and enhances insulin-stimulated glucose transport in 3T3-L1 adipocytes via a cholesterol-dependent mechanism. Mol Endocrinol. 2006; 20(4): 857-870.

54. Chen Y, Watson HM, Gao J, Sinha SH, Cassady CJ, Vincent JB. Characterization of the organic component of low-molecular-weight chromium-binding substance and its binding of chromium. J Nutr. 2011; 141(7): 1225-1232.

55. Peterson RL, Banker KJ, Garcia TY, Works CF. Isolation of a novel chromium(III) binding protein from bovine liver tissue after chromium(VI) exposure. J Inorg Biochem. 2008; 102(4): 833-841.

56. Stearns DM. Multiple hypotheses for chromium(III) biochemistry: why the essentiality of chromium(III) is still questioned. In: Vincent JB, editor. The nutritional biochemistry of chromium(III). Amsterdam, Elsevier, 2007. p.57-70.

57. Balamurugan K, Rajaram R, Ramasami T, Narayanan S. Chromium(III)induced apoptosis of lymphocytes: death decision by ROS and Srcfamily tyrosine kinases. Free Radic Biol Med. 2002; 33(12): 1622-1640.

58. Pattar GR, Tackett L, Liu P, Elmendorf JS. Chromium picolinate positively influences the glucose transporter system via affecting cholesterol homeostasis in adipocytes cultured under hyperglycemic diabetic conditions. Mutat Res. 2006; 610(1-2): 93-100.

59. Raja NS, Sankaranarayanan K, Dhathathreyan A, Nair BU. Interaction of chromium(III) complexes with model lipid bilayers: implications on cellular uptake. Biochim Biophys Acta. 2011; 1808(1): 332-340.

60. Song RX, Barnes CJ, Zhang Z, Bao Y, Kumar R, Santen RJ. The role of Shc and insulin-like growth factor 1 receptor in mediating the translocation of estrogen receptor alpha to the plasma membrane. Proc Natl Acad Sci U S A. 2004; 101(7): 2076-2081.

61. Mumtaz MM, Tully DB, El-Masri HA, De Rosa CT. Gene induction studies and toxicity of chemical mixtures. Environ Health Perspect. 2002; 110(6): 947-956.

62. Choe SY, Kim SJ, Kim HG, Lee JH, Choi Y, Lee H, et. al. Evaluation of estrogenicity of major heavy metals. Sci Total Environ. 2003; 312(1-3): $15-21$.

63. Lewicki S. Ocena wpływu jonów chromu (III) podawanych w formie chlorku lub pikolinianu na białka ścieżki przekaźnictwa insulinowego oraz receptory estrogenowe $\alpha$ i $\beta$. Warszawa, SGGW, 2010.

64. Chan JC, Malik V, Jia W, Kadowaki T, Yajnik CS, Yoon KH, et al. Diabetes in Asia: epidemiology, risk factors, and pathophysiology. JAMA. 2009; 301(20): 2129-2140.

65. Air EL, Kissela BM. Diabetes, the metabolic syndrome, and ischemic stroke: epidemiology and possible mechanisms. Diabetes Care. 2007; 30(12): 3131-3140.

66. Prentice AM. The emerging epidemic of obesity in developing countries. Int J Epidemiol. 2006; 35(1): 93-99.

67. Chen Y, Quick WW, Yang W, Zhang Y, Baldwin A, Moran J, et al. Cost of gestational diabetes mellitus in the United States in 2007. Popul Health Manag. 2009; 12(3): 165-174.

68. Sundararaman PG, Sridhar GR, Sujatha V, Anita V. Serum chromium levels in gestational diabetes mellitus. Indian J Endocrinol Metab. 2012; $1: 70-73$.
69. Wysocka E, Cymerys M, Mielcarz G, Bryl W, Dzięgielewska S, Torliński L. The way of serum chromium utilization may contribute to cardiovascular risk factors in centrally obese persons Arch Med Sci. 2011; 7(2): 257-263.

70. Kuryl T, Debski B, Martinik K. The effect of microelements supplementation on beta-oxidation activity in healthy and type 1 diabetic rats. Cent Eur J Public Health. 2008; 16(4): 205-208.

71. Ryan GJ, Wanko NS, Redman AR, Cook CB. Chromium as adjunctive treatment for type 2 diabetes. Ann Pharmacother. 2003; 37(6): 876-885.

72. Komorowski JR, Tuzcu M, Sahin N, Juturu V, Orhan C, Ulas M, et al. Chromium picolinate modulates serotonergic properties and carbohydrate metabolism in a rat model of diabetes. Biol Trace Elem Res. 2012; 149(1): 50-56.

73. Cefalu WT, Hu FB. Role of chromium in human health and in diabetes. Diabetes Care. 2004; 27(11): 2741-2751.

74. Hutchinson DS, Bengtsson T. a1A-Adrenoceptors Activate Glucose Uptake in L6 Muscle Cells through a Phospholipase C-, Phosphatidylinositol-3 Kinase-, and Atypical Protein Kinase C-Dependent Pathway. Endocrinol. 2005; 146(2): 901-912.

75. Wang ZQ, Zhang XH, Russell JC, Hulver M, Cefalu WT. Chromium picolinate enhances skeletal muscle cellular insulin signaling in vivo in obese, insulin-resistant JCR:LA-cp rats. J Nutr. 2006; 136(2): 415-420.

76. Racek J, Trefil L, Rajdl D, Mudrová V, Hunter D, Senft V. Influence of chromium-enriched yeast on blood glucose and insulin variables, blood lipids, and markers of oxidative stress in subjects with type 2 diabetes mellitus. Biol Trace Elem Res. 2006; 109(3): 215-230.

77. Cefalu WT, Rood J, Pinsonat P, Qin J, Sereda O, Levitan L, et al. Characterization of the metabolic and physiologic response to chromium supplementation in subjects with type 2 diabetes mellitus. Metabolism. 2010; 59(5): 755-762.

78. Sharma S, Agrawal RP, Choudhary M, Jain S, Goyal S, Agarwal V. Beneficial effect of chromium supplementation on glucose, HbA1C and lipid variables in individuals with newly onset type-2 diabetes. J Trace Elem Med Biol. 2011; 25(3): 149-153.

79. Drake TC, Rudser KD, Seaquist ER, Saeed A. Chromium infusion in hospitalized patients with severe insulin resistance: a retrospective analysis. Endocr Pract. 2012; 18(3): 394-398.

80. Surani SR, Ratnani I, Guntupalli B, Bopparaju S. Severe insulin resistance treatment with intravenous chromium in septic shock patient. World J Diabetes. 2012; 3(9): 170-173.

81. Jain SK, Kahlon G, Morehead L, Dhawan R, Lieblong B, Stapleton $\mathrm{T}$, et al. Effect of chromium dinicocysteinate supplementation on circulating levels of insulin, TNF- $\alpha$, oxidative stress, and insulin resistance in type 2 diabetic subjects: Randomized, double-blind, placebo-controlled study. Mol Nutr Food Res 2012; 56(8): 1333-1341.

82. Cefalu WT, Rood J, Pinsonat P, Qin J, Sereda O, Levitan L, et al. Characterization of the metabolic and physiologic response to chromium supplementation in subjects with type 2 diabetes mellitus. Metabolism. 2010; 59(5): 755-762.

83. Lau FC, Bagchi M, Sen CK, Bagchi D. Nutrigenomic basis of beneficial effects of chromium(III) on obesity and diabetes. Mol Cell Biochem. 2008; 317(1-2): 1-10.

84. Tuzcu M, Sahin N, Orhan C, Agca CA, Akdemir F, Tuzcu Z, et al. Impact of chromium histidinate on high fat diet induced obesity in rats. Nutr Metab (Lond). 2011; 8: 28.

85. Iqbal N, Cardillo S, Volger S, Bloedon LT, Anderson RA, Boston R, et al. Chromium picolinate does not improve key features of metabolic syndrome in obese nondiabetic adults. Metab Syndr Relat Disord. 2009; 7(2): 143-150.

86. Balk EM, Tatsioni A, Lichtenstein AH, Lau J, Pittas AG. Effect of chromium supplementation on glucose metabolism and lipids: a systematic review of randomized controlled trials. Diabetes Care. 2007; 30(8): 2154-2163.

87. Wang ZQ, Cefalu WT. Current concepts about chromium supplementation in type 2 diabetes and insulin resistance. Curr Diab Rep. 2010; 10(2): 145-151.

88. Lukaski HC, Siders WA, Penland JG. Chromium picolinate supplementation in women: effects on body weight, composition, and iron status. Nutrition. 2007; 23(3): 187-195.

89. Yazaki Y, Faridi Z, Ma Y, Ali A, Northrup V, Njike VY, et al. A pilot study of chromium picolinate for weight loss. J Altern Complement Med. 2010; 16(3): 291-299.

90. Nachtigal MC, Patterson RE, Stratton KL, Adams LA, Shattuck AL, White E. Dietary supplements and weight control in a middle-age population. J Altern Complement Med. 2005; 11(5): 909-915.

91. Masharani U, Gjerde C, McCoy S, Maddux BA, Hessler D, Goldfine ID, et al. Chromium supplementation in non-obese non-diabetic subjects is associated with decline in insulin sensitivity. BMC Endocr Disord 2012; 12: 31. 